\title{
圧電フイルムを用いたアーチ構造物のアクティブ制振実験 ACTIVE VIBRATION CONTROL TESTS OF ARCH STRUCTURES USING PIEZOELECTRIC FILMS
}

\author{
熊谷知彦 ${ }^{* 1}$, 箕輪 健一 ${ }^{* 2}$, 桑 原諒子 ${ }^{* 3}$, 小河利 行*4 \\ Tomohiko KUMAGAI, Ken' ichi MINOWA, Ryoko KUWAHARA \\ and Toshiyuki OGAWA
}

\begin{abstract}
The present paper discusses the active vibration control of arch structures on the Optimal Control Theory by vibration tests. The controlled objects are arch structures. We try to control the scale model's responses of arch structures with piezoelectric films. Here, a DSP (Digital Signal Processing) is used for the controller. The responses are measured with laser displacement sensors. The control force is added to the arch structure by piezoelectric films installed in the arch structure. The main purpose of this paper is to grasp the fundamental characteristic of the active vibration control of spatial structures. Specifically, the influences of delay time and phase of control input on the control results are analyzed. First, a control system is designed in consideration for the effects of delay time and noise. Then, active vibration control tests are carried out using the scale models of arch structures. Finally, we weigh the results of numerical analyses with those of active vibration control tests.
\end{abstract}

Keywords : Arch structure, Active vibration control test, Piezoelectric film, Optimum control theory, Delay time, Phase difference アーチ構造物，アクティブ制振実験，圧電フィルム，最適制御理論，遅れ時間，位相差

1. 序

近年, シェル・空間構造物において, 震災時における屋根部材の 落下といった被害が目立っており，対策を講じることへの社会的要 求が高まっている。屋根部材が落下寸る原因の一つとして考えられ るのが，地震時の水平方向への入力に対する鉛直方向の振動が励起 される特性である。このような被害を低減するために，様々な制振

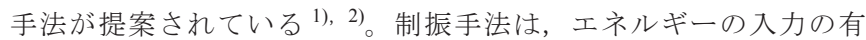
無により，大きくパッシブ制振とアクティブ制振に分類される。

屋根構造自体のパッシブ制振に関する研究には，以下のような ものがある。山田（大）ら ${ }^{3)}$ は単層ラチスドームの制震を目的に, 効果的・効率的な TMD (Tuned Mass Damper) の設定および配置につ いて検討している。吉中ら ${ }^{4)}$ ，5) は分散型 MTMD (Multiple TMD) を 空間構造に付加することを提案し, 解析的かつ実験的に振動制御の 有効性を確認している。また，著者ら ${ }^{6}$ も，アーチ構造物に複数 の TMD を搭載することによる，制振効果の検討を行っている。

一方，アクティブ制振に関する研究には，以下のようなものがあ る。著者 7)らは, 最適制御理論を適用することで, アーチ構造物 の地震応答が低減可能であることを数值解析により示している。こ こでは，卓越モードの腹近傍に曲げモーメントを加える制御が，効

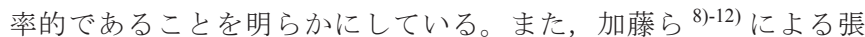
弦梁構造の張力を能動的に制御する研究, 桜井ら ${ }^{13)-15)}$ によるアー チを対象とした圧電アクチュエータを用いた研究も行われている。

しかし，シェル・空間構造物を対象としたアクティブ制振に関す る研究が，実用化に向けて十分に行われているとは言えない。アク ティブ制振の実用化には，モデルの不確かさや遅れ時間などといっ た問題点から生じる制御の困難さが付随する。このため，数值解析 のみならず，実験による制振効果の検討が強く望まれるものの，ア クティブ制振に関する実験的検証はほとんど行われていない。

そこで本研究では, 固有周期の近接した複数のモードが励起され るシェル・空間構造物に適していると考えられる最適制御理論を用 いた地震応答制御の実現に向けて, アーチ構造物の縮小模型を用い たアクティブ制振実験を行う。本研究の主目的は，アクティブ制振 の実験的な検証を行うことで，制御効果への遅れ時間の影響，制御 力の応答に対する位相差の影響等を分析することである。

制御効果一の遅れ時間の影響に関する研究は古くから行われ，建 築分野に限れば，久保ら ${ }^{16)}$ による安定な制御系を構成する時間遅 れの周期性に関寸る研究や，佐藤ら ${ }^{17)}$ による制御力の駆動時間遅 れの不確かさに関する研究がある。それに併せ，遅れ時間を補償す

*1 東京工業大学大学院理工学研究科建築学専攻 助教・博士 (工学)

*2 東京工業大学大学院理工学研究科建築学専攻 博士後期課程 · 修士 (工学)

*3 国土交通省 修士 (工学) (元 東京工業大学大学院 大学院生)

*4 東京工業大学大学院理工学研究科建築学専攻 教授. 工博
Assist. Prof., Dept. of Arch. and Building Eng., Tokyo Institute of Technology, Dr. Eng.

Graduate Student, Dept. of Arch. and Building Eng., Tokyo Institute of Technology, M. Eng.

Ministry of Land, Infrastructure, Transport and Tourism, M. Eng.

(Former Graduate Student, Tokyo Institute of Technology)

Prof., Dept. of Arch. and Building Eng., Tokyo Institute of Technology, Dr. Eng. 
るための制御方法としては，位相進み補償，位相遅れ補償による補 償 ${ }^{18)}$ や，遅れ時間をモデル化し対象システムに拡大系として組み 込む方法や，美多ら ${ }^{19)}$ による並列演算方式による演算時間を考慮 した制御方法や矢島ら ${ }^{20)}$ による実数次位相進み遅れ補償器を用い た制御方法などが提案されている。本研究では，遅れ時間の補償方 法として, 位相遅れ補償を参考に, バンドパスフィルタの位相特性 を利用して位相を調節する方法を用いる。

本研究では, 制御力を入力するデバイスであるアクチュエータと して, 本試験体の制御に要する制御力の大きさを考慮し, 圧電フィ ルムを採用する。近年, 圧電フィルムは, 即応性が高くスマート材 料として注目されている。このため, 機械工学の分野においては, 以下に示すように柔軟構造物を対象とした圧電フィルムのアクチュ エータとしての性能に関寸る研究が数多く見られる。谷ら ${ }^{21)}$ は, アーチを対象として $\mathrm{H}^{\infty}$ 制御を用いて圧電フィルムにより曲げモー メントを加えることで, 横振動を抑える効果を検討している。圧電 フィルムのアクチュエータとしての性能を検討した研究としては, 江ら ${ }^{22)}$ の研究が挙げられる。また, Banks ら ${ }^{23)}$ は円筒シェル面の 振動やノイズに対寸る圧電フィルムのアクチュエータとしての性能 を論じている。しかし, これらの対象構造物は, $1000 \mathrm{~mm}$ 以下の規 模の小さいものに限られる。圧電フィルムの実構造物への適用の可 能性は, 今後の研究開発に依存寸る。現状，実構造物に用いられる アクチュエータとしては, 積層形圧電素子や油圧シリンダーなどが 挙げられる。

本報では，まず 2 章において，アーチ構造物のアクティブ制振実 験の概要を説明する。ここでは, 試験体および実験概要について述 べる。次に, 3 章において, 制御システムについて説明する。ここ

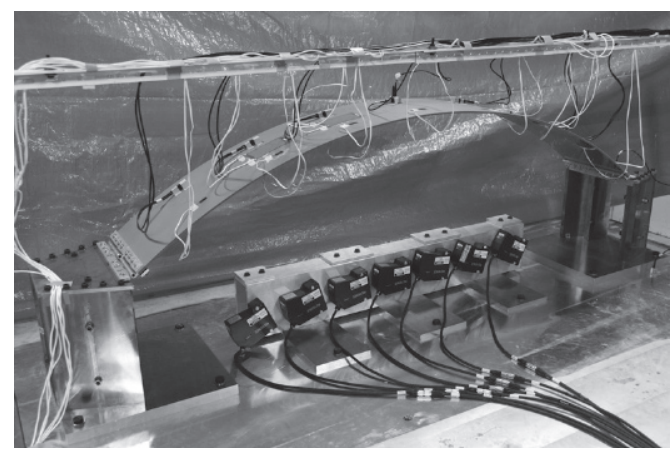

写真 1 アクティブ制振対象のアーチ構造物

表 1 アーチ屋根の形状諸元

\begin{tabular}{|c|c|c|c|c|}
\hline $\begin{array}{c}\text { スパン } \\
L_{x}(\mathrm{~mm})\end{array}$ & $\begin{array}{c}\text { 幅 } \\
L_{y}(\mathrm{~mm})\end{array}$ & $\begin{array}{c}\text { ライズ } \\
H(\mathrm{~mm})\end{array}$ & $\begin{array}{c}\text { 曲率半径 } \\
R(\mathrm{~mm})\end{array}$ & $\begin{array}{c}\text { 半開角 } \\
\Theta(\mathrm{deg} .)\end{array}$ \\
\hline 1500 & 250 & 236 & 1308 & 35 \\
\hline
\end{tabular}

表 2 アーチ屋根の材料諸元

\begin{tabular}{|c|c|c|c|c|c|}
\hline モデル名 & 材質 & $\begin{array}{c}\text { 板厚 } \\
t(\mathrm{~mm})\end{array}$ & $\begin{array}{l}\text { ヤング率 } \\
E\left(\mathrm{~N} / \mathrm{mm}^{2}\right) \\
\end{array}$ & $\begin{array}{r}\text { 引張強さ } \\
\left(\mathrm{N} / \mathrm{mm}^{2}\right) \\
\end{array}$ & $\begin{array}{c}\text { 破断ひずみ } \\
\varepsilon_{b}(\%)\end{array}$ \\
\hline $\mathrm{Ra} 0.2$ & \multirow{2}{*}{$\begin{array}{c}\text { アクリル樹脂 } \\
\text { (アクリライト } \mathrm{R} \text { ) }\end{array}$} & 5.18 & \multirow{2}{*}{$3.10 \times 10^{3}$} & \multirow{2}{*}{61.8} & \multirow{2}{*}{3.8} \\
\hline $\mathrm{Ra} 0.4$ & & 3.07 & & & \\
\hline
\end{tabular}

\begin{tabular}{|c|c|c|c|}
\multirow{2}{*}{ 表 3 制御入力位置 } \\
\hline \multirow{2}{*}{ 制御タイプ } \\
\cline { 2 - 4 } & 3 & \multicolumn{3}{|c|}{ 点番号 } \\
\hline $1 \mathrm{M} 1$ & $\circ$ & - & - \\
\hline $1 \mathrm{M} 3$ & - & $\circ$ & - \\
\hline $2 \mathrm{M} 1 \mathrm{~s}$ & $\circ$ & - & $\circ$ \\
\hline $2 \mathrm{M} 1 \mathrm{a}$ & $\circ$ & $\circ$ & - \\
\hline
\end{tabular}

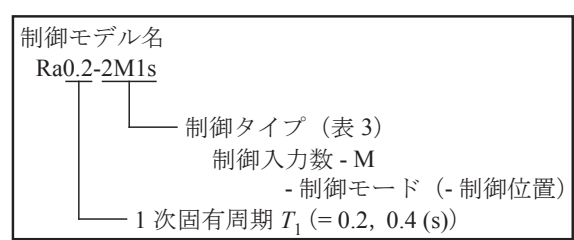

では，本研究で用いた制御装置および制御系の設計方法，位相の調 節方法について記述する。4 章においては，アクティブ制振実験の 結果について考察する。特に, 制御時におけるアーチ構造物の応答 性状について, 制御力と応答の位相差, 制御入力数などに着目して 考察する。最後に，5章において，制御時の遅れ時間を考慮した時 刻歴応答解析によりアクティブ制振を行う。ここでは, 実験結果と 解析結果の対応を分析する。

\section{2. アーチ構造物のアクティブ制振実験の実験計画}

\section{1. 試験体および実験概要}

制振対象の試験体は写真 1 ，図 1 に示すアーチ構造物である。本 試験体は，スパン $60 \mathrm{~m}$ で固有周期 $0.3 \mathrm{~s}$ 程度の複層卜ラスからな るアーチ構造物を想定している。試験体の形状諸元を表 1 に示す。 試験体のスパン $L_{x}$ は $1500 \mathrm{~mm}$, 幅 $L_{y}$ は $250 \mathrm{~mm}$, ライズ $H$ は 236 $\mathrm{mm}$, 半開角 $\Theta$ は $35 \mathrm{deg}$. である。試験体の材料特性を表 2 に示す。 アーチ屋根の材料は, アクリル樹脂（三菱レイヨン社製・アクリラ イト $\mathrm{R} S \mathrm{~S})$ である。屋根の材料は, 固有周期を $0.3 \mathrm{~s}$ に合わせた際に, 片面に貼った圧電フィルムにより，より大きな曲げモーメントが発 生する板厚となるように選定した。試験体は，アクリル樹脂の板厚 が異なる 2 種類とする。板厚は, 屋根の 1 次固有周期 $T_{1}$ が $0.2 \mathrm{~s}$ お よび $0.4 \mathrm{~s}$ となるように，それぞれ $5 \mathrm{~mm}$ および $3 \mathrm{~mm}$ に設定する。 なお，それぞれの試験体を，1 次固有周期 $T_{1}$ を基に, $\mathrm{Ra} 0.2$ モデル, $\mathrm{Ra} 0.4$ モデルと呼ぶ。アーチ屋根の質量は，Ra0.2 モデルで $2.8 \mathrm{~kg}$, $\mathrm{Ra} 0.4$ モデルで $1.7 \mathrm{~kg}$ ある。

実験装置および計測位置を図 2 に示す。載荷には，0.1〜 $100 \mathrm{~Hz}$ において最大加振力 $19.6 \mathrm{kN}$, 最大加速度 $14.7 \mathrm{~m} / \mathrm{s}^{2}$ で載荷可能なサ ンエス社製の永久磁石方式の振動台を用いる。アーチ屋根と支持 台との境界部は，蝶番によりピン支持を表現する。屋根面の応答 は，レーザー変位計，加速度計，ひずみゲージにより計測する。制 御のためのアクチュエータには圧電フィルム（Smart Material 社製・

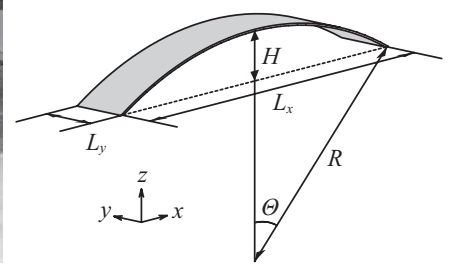

図 1 アーチ屋根の試験体形状
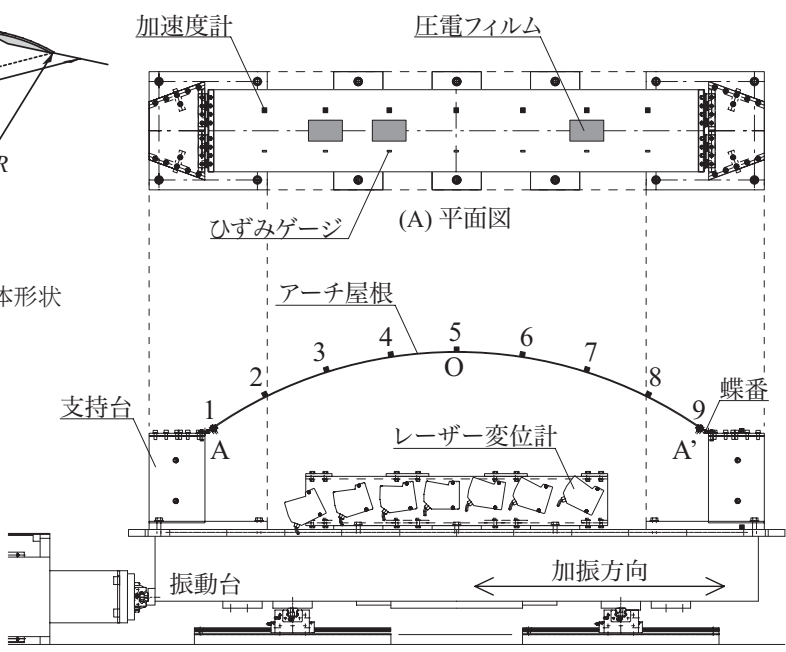

(B) 立面図

図 2 実験装置および計測位置

表 4 人力波

\begin{tabular}{|c|c|c|c|c|c|c|}
\hline モデル名 & \multicolumn{3}{|c|}{$\mathrm{Ra} 0.2$} & \multicolumn{3}{c|}{$\mathrm{Ra} 0.4$} \\
\hline 入力波 & sine1 波 & sine3 波 & 地震波 & sine1 波 & sine3 波 & 地震波 \\
\hline 振幅 $\left(\mathrm{cm} / \mathrm{s}^{2}\right)$ & 30 & 40 & 100 & 20 & 20 & 100 \\
\hline 時間軸 & - & - & $1 / 2$ 倍 & - & - & 1 倍 \\
\hline
\end{tabular}


M8557-P1）を用い， Ra0.2 モデルでは点 3， 4, 7 の上面に, Ra0.4 モデルでは点 $3 ， 4$ の上面に, エポキシ樹脂により接着する。表 3 に各制御モデルの制御入力位置を，表 3 右に制御モデル名を示寸。 制御モデル名は, 試験体および制御入力位置で定義し, Ra（1 次固 有周期 $T_{1}$ ) - (制御入力数) M（制御モード [制御位置]）とする。

入力波は，後述する各モデルの固有周期と同周期の正弦波（1 次 固有周期 : sine 1 波, 3 次固有周期 : sine 3 波), 人工地震波 BCJ-L1, 観測地震波 El Centro NS (1940) および JMA Kobe NS (1995) とする。 入力波の一覧を表 4 に示寸。入力波の最大加速度は, アーチ構造物 の応答が弾性範囲に収まるように, sine 波では $20 \sim 40 \mathrm{~cm} / \mathrm{s}^{2}$, 地震 波では $100 \mathrm{~cm} / \mathrm{s}^{2}$ に基準化する。なお， Ra0.2 モデルに入力する各地 震波は, 時間軸を $1 / 2$ 倍に縮小して用いる。

\section{2. アーチ構造物の振動特性}

本節では, 試験体の基本的な振動特性を示す。まず，固有周期を， スイープ試験により計測した応答のフーリエ振幅スペクトルの卓越 周期から求める。得られた試験体の振動特性を表 5 に示す。 1 次固 有周期は, $\mathrm{Ra} 0.2$ モデルでは $0.174 \mathrm{~s}, \mathrm{Ra} 0.4$ モデルでは $0.355 \mathrm{~s}$ とな り, 目標値よりやや短くなった。なお, 減衰定数 $h$ は, アーチ構造 物が多自由度系であるものの共振点が近接していないことから，共 振点付近の周波数応答関数が 1 自由度系に近似できるとみなし, 式 (1)により算出した ${ }^{24)}$ 。

$$
h=\sqrt{\frac{1}{2}\left(\frac{X_{\text {max }}^{2}}{X_{\text {max }}^{2}-1}-\sqrt{\frac{X_{\text {max }}^{2}}{X_{\text {max }}^{2}-1}}\right)}
$$

ここに, $X_{\max }$ は最大振動伝達率であり, スイープ加振時の法線方向 の応答変位を入力波の最大変位 $D_{g}$ で除して求める。

減衰定数は，モデルおよびモードによらず $10 \%$ 程度であった。こ れらの值は想定する実構造物の值 (2\%) よりも大きい。これはア クリル樹脂の特性によるものと考えられる。

次に, 固有モード形状を, 固有周期と同周期の sine 波入力時の 応答から得る。 Ra0.2 モデルの固有モード形状を図 3 に示寸。逆対 称 1 波および逆対称 2 波のモードが計測され，それぞれを 1 次モー ドおよび 3 次モードと呼ぶ。

\section{3. 制御システム}

\section{1. 制御装置および制御系の設計}

制御対象であるアーチ構造物の振動の制御は, 最適制御理論 ${ }^{7)}$ を用いたアクティブ制御により行う。本節では，制御装置および制 御系の設計方法を示寸。

アクチュエータには, 即応性が高く, 発生力の大きい写真 2 に示 寸前述の圧電フィルムを用いる。圧電フィルムの形状諸元を表 6 に 示す。コントローラには, デジタル信号処理に特化したマイクロプ ロセッサである Digital Signal Processor (DSP)（mtt 社製・s-BOX）を 用いる。なお，DSPへの実装には Real-Time Workshop 7.1 を用い, 制御のサンプリング周期は $1 \mathrm{~ms}$ とする。また, センサにはレーザー 変位計を用い, 加振面に対寸るアーチ屋根面の相対変位をフィード バックする。応答変位の計測方向は法線方向であり, 計測点の屋根 の傾きを用いて水平および鋁直方向に分解する。

アーチ構造物のアクティブ制振の概念図を図 4 に示す。まず, レー ザー変位計のデータを電圧に変換し, DSP に入力する。DSP ゙は,

表 5 アーチ屋根の振動特性

\begin{tabular}{|c|c|c|c|c|c|c|}
\hline \multirow{2}{*}{ モデル } & \multicolumn{3}{|c|}{1 次モード } & \multicolumn{3}{|c|}{ 3 次モード } \\
\cline { 2 - 7 } & $\begin{array}{c}\text { 固有周期 } \\
T_{1}(\mathrm{~s})\end{array}$ & $\begin{array}{c}\text { 減衰 } \\
h_{1}(\%)\end{array}$ & $\begin{array}{c}\text { 有効質量比 } \\
M_{e} / M_{R}(\%)\end{array}$ & $\begin{array}{c}\text { 固有周期 } \\
T_{3}(\mathrm{~s})\end{array}$ & $\begin{array}{c}\text { 減衰 } \\
h_{3}(\%)\end{array}$ & $\begin{array}{c}\text { 有効質量比 } \\
M_{e} / M_{R}(\%)\end{array}$ \\
\hline $\mathrm{Ra} 0.2$ & 0.174 & 9.2 & 29.6 & 0.0365 & 11.2 & 4.65 \\
\hline $\mathrm{Ra} 0.4$ & 0.355 & 12.5 & 26.8 & 0.0668 & 12.6 & 2.06 \\
\hline
\end{tabular}

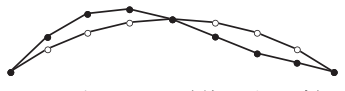

(a) 1 次モード (逆対称 1 波) 図 3 固有モード形状 (Ra0.2 モデル)

駆動部分の長さ

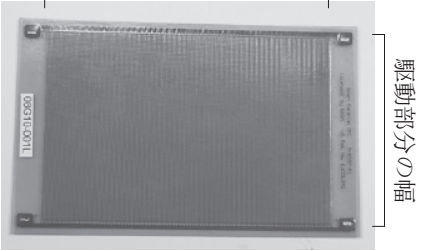

表 6 圧電フィルムの形状諸元

\begin{tabular}{|c|c|c|}
\hline \multicolumn{2}{|c|}{ 製品名 } & M8557-P1 \\
\hline \multirow{2}{*}{ 駆動部分 } & 長さ (mm) & 85 \\
\hline & 幅 (mm) & 57 \\
\hline \multirow{2}{*}{ 外形 } & 長さ $(\mathrm{mm})$ & 103 \\
\hline & 幅 (mm) & 64 \\
\hline
\end{tabular}

写真 2 圧電フィルム

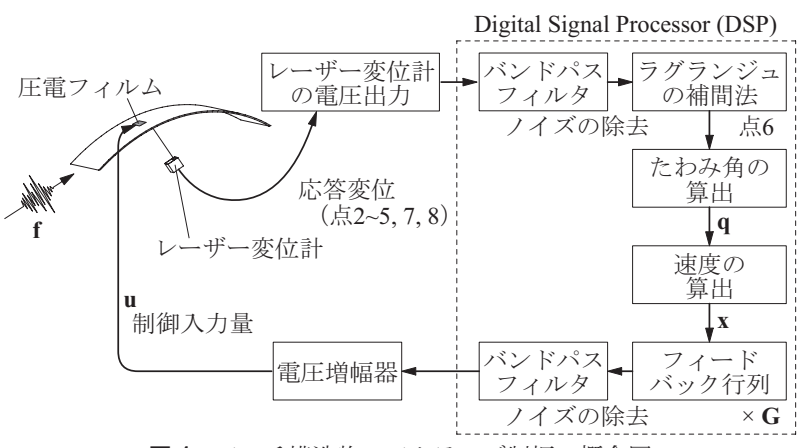

図 4 アーチ構造物のアクティブ制振の概念図

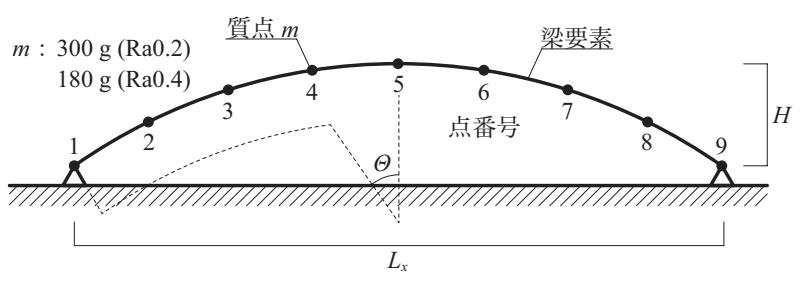

図 5 アーチ構造物の 9 質点系モデル

これらのデータと最適制御理論により求めたフィードバック行列 $\mathbf{G}$ により, リアルタイムで制御力が算出される。ここで, 制御力は, 圧電フィルムに印加するための電圧として算出される。この電圧が 電圧増幅器を介して圧電フィルムに印加されることで, 圧電フィル ムが制御力を発生し, アーチ構造物の振動制御が行われる。

本研究では, コントローラの設計には文献 7) と同様の最適制御 理論を用いる。最適制御理論は, 多自由度, 多入力の応答制御が可 能であるため, 固有周期の近接した複数のモードが励起されるシェ ル・空間構造物に対しても適していると考えられる。最適制御理論 を適用するために，まず，アーチ屋根をモデル化し運動方程式を作 成する。ここで，アーチ屋根は，逆対称 2 波である 3 次モードを表 現可能な, 図 5 に示寸 9 質点系にモデル化する。部材要素は梁要素 である。減衰は Rayleigh 型とし, 表 5 に示す減衰定数を設定する。 また，質量は集中質量とする。なお，制御力 $\mathbf{u}$ を算出するフィード バック行列 $\mathbf{G}$ は, 式 (2) に示寸評価関数 $J$ が最小となるように定め られ, Riccati の行列方程式を解くことで得られる。 


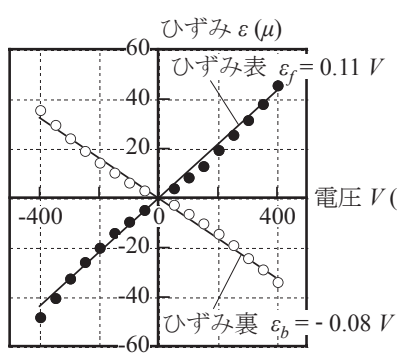

図 6 圧電フィルムの ひずみ $\varepsilon-$ 電圧 $V$ 特性 $(\mathrm{Ra} 0.2$ ，点 3$)$

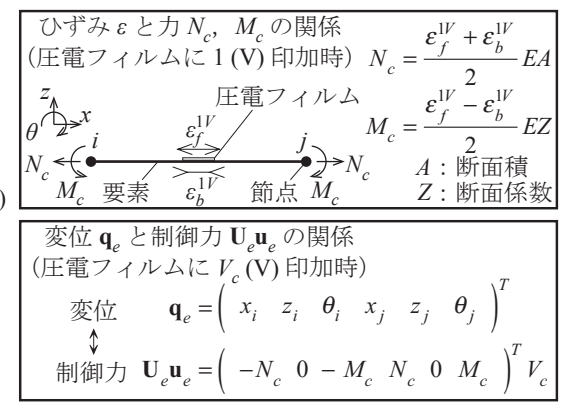

図 7 制御力の要素係数マトリクス $\mathbf{U}_{e}$ の算出方法

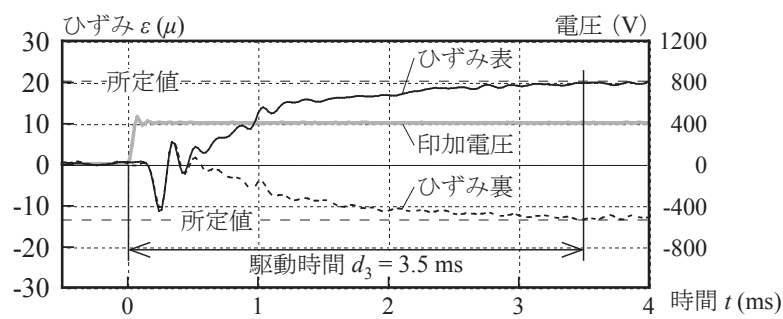

図 8 電圧印加直後の圧電フィルムによるひず夕応答 $(\operatorname{Ra} 0.2$, 点 3, $400 \mathrm{~V}$ 印加時)

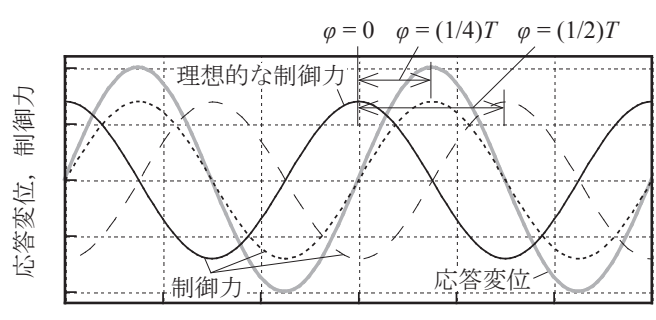

図 9 応答変位と制御力の位相差 $\varphi$ の概念図

$$
J=\int_{0}^{\infty}\left\{\mathbf{x}^{T} \mathbf{Q} \mathbf{x}+\mathbf{u}^{T} \mathbf{R u}\right\} d t
$$

ここに, $\mathbf{x}$ は応答速度, 応答変位からなる状態変数ベクトルであり,

$\mathbf{Q}, \mathbf{R}$ は応答低減効果と制御入力量とのバランスを決める重み行列 である。

本研究では, 重み行列 $\mathbf{Q}$ を単位行列とし， $\mathbf{R}$ は目標とする応答值 を非制御時の $r$ 倍として算出する。以下, $r$ を目標とする応答比 に関する係数と呼ぶ。なお，制御系の設計には，MATLAB 7.10.0/ Simulink 7.5 を用いる。

なお， DSP (s-BOX) の入力数の上限が 6 個であるために，点 6 の 応答変位については点 $2 \sim 5,7,8$ の応答変位より, ラグランジェ の補間法を用いることで算出する。また，たわみ角 $\theta$ も同様にラグ ランジュの補間法を用いて算出する。なお，本実験における制御系 の設計においては, 状態変数ベクトル $\mathbf{x}$ 作成のために振動台上に設 置したレーザー変位計によって応答変位を計測している。そのた め，実構造物への本システムの適用においては，屋根面上に設置可 能な速度計を用いる等が適当な方法となる。

図 4 に示寸ように, バンドパスフィルタ (BPF) によって, レーザー 変位計で計測したデータに含まれるノイズを除去する。ここでは, 式 (3) に示すハイパスフィルタ (HPF) および式 (4), (5) に示すロー パスフィルタ $(\mathrm{LPF})$ を用いる。

$$
\begin{gathered}
\text { HPF : } H(s)=\frac{s}{s+\omega_{h c}} \\
\text { LPF : } H(s)=\prod_{k=1}^{5} \frac{\omega_{l c}}{s-s_{k}} \\
s_{k}=\omega_{l c} \exp \left\{j\left(\frac{k+2}{5}\right) \pi\right\}
\end{gathered}
$$

ここに, $\omega_{h c}, \omega_{l c}$ はカットオフ周波数 $(\mathrm{rad} / \mathrm{s})$ である。

HPF は 1 次の, LPF は 5 次のバターワース型フィルタである。なお, BPF を用いることで入力と出力に位相差が生じる。 3.3 節にて述べ るように，この位相差を利用して制御力の位相を調節する。

\section{2. アクチュエータに用いる圧電フィルムの諸特性}

圧電フィルムは, 力を加えて歪ませると電圧を発生する圧電効果 と, 電圧を加えるとひずみあるいは応力を発生する逆圧電効果を有 する。本研究では, 逆圧電効果を用いてアーチ屋根の応答を制御す
る。圧電フィルムのひずみ $\varepsilon$-電圧 $V$ 特性を図 6 に示す。図中の線は, 最小二乗法により求めた近似線である。電圧とひずみの関係は, ほ ぼ線形である。つまり, 制御力は電圧と比例関係にあるとみなすこ とができる。ここで, 図 7 に制御力の要素係数マトリクス $\mathbf{U}_{e}$ の算 出方法を示す。図 6 により得られたひずみ $\varepsilon$ - 電圧 $V$ 特性の傾きか ら, $1 \mathrm{~V}$ 印加時に発生するひずみ $\varepsilon_{f}{ }^{1 V}, \varepsilon_{b}{ }^{1 V}$ を求め, 軸力 $N_{c}$ と曲げモー メント $M_{c}$ の項を算出する。

電圧の印加に対する圧電フィルムによるアーチ屋根のひずみ応答 を図 8 に示す。圧電フィルムが所定の制御力を発生するまでには駆 動時間 $d_{3}$ を要する。この駆動時間は $3.5 \mathrm{~ms}$ であった。なお, 印加 電圧の急激な増加により, 電圧印加直後に振動が発生している。

圧電フィルムに印加する電圧には, 電圧増幅器の最大出力 $( \pm 600$ V）に伴う上限値が存在する。電圧増幅器により増幅された電圧が $\pm 600 \mathrm{~V}$ を超える場合は, その部分で印加電圧の波形が欠ける。こ の現象は, 目標とする応答比に関する係数 $r$ が 0.8 以下で発生する 場合があった。このため，係数 $r$ は $0.8,0.85,0.9$ と設定した。

\section{3. 遅れ時間に伴う制御力の位相の調節}

フィードバック制御では，リアルタイムでの制御が望まれるもの の, 制御力の算出などに時間を要し, タイムラグが発生する。以 下，このようなタイムラグを遅れ時間と呼ぶ。表 7 に遅れ時間を示 す。本制御系では，レーザー変位計のデータを電圧に処理すると き, DSP が制御力を算出するとき，圧電フィルムが駆動するとき に時間を要する。これらの合計を, 本制御系における遅れ時間 $d$ と 定義する。レーザー変位計の電圧出力におけるデータ処理時間 $d_{1}$ は $2.5 \mathrm{~ms}$, 圧電フィルムが所定の制御力を発生するまでに要する駆 動時間 $d_{3}$ は約 $3.5 \mathrm{~ms}$ である。これらに比較し, DSP における制御 力の算出時間 $d_{2}$ は $12 \mathrm{~ms}$ および $72 \mathrm{~ms}$ と長く, 遅れ時間の約 $7 \sim 9$ 割を占めている。結果として, 遅れ時間は Ra0.2 モデルでは $18 \mathrm{~ms}$, $\mathrm{Ra} 0.4$ モデルでは $78 \mathrm{~ms}$ であった。 1 次固有周期に対する遅れ時間は, $\mathrm{Ra} 0.2$ モデルでは $10 \%$ に, Ra0.4 モデルでは $22 \%$ に相当する。なお, $\mathrm{Ra} 0.2$ モデルよりも Ra0.4 モデルの遅れ時間が長い理由は不明であ る。最適制御理論に基づくアクティブ制振では, 制御対象構造物の モデル化に従い, 寸べての点の応答をフィードバックしなくてはな 


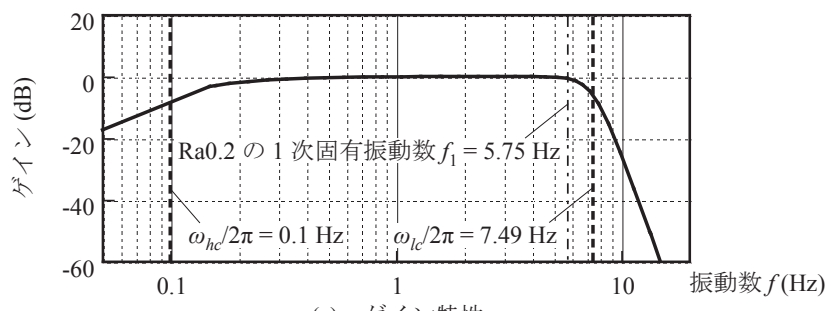

(a) ゲイン特性

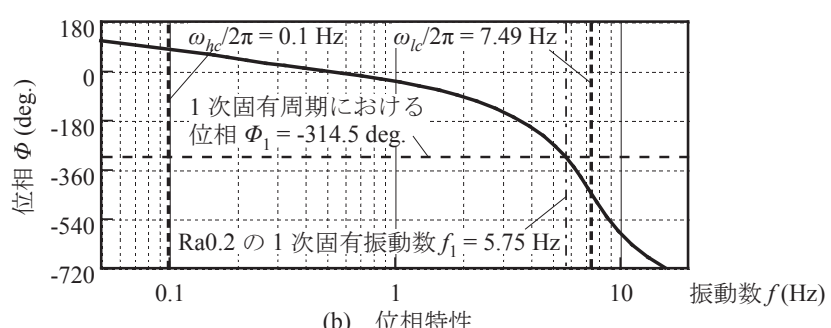

(b) 位相特性

図 10 バンドパスフィルタの周波数特性 $(\mathrm{Ra} 0.2-1 \mathrm{M} 1, \varphi=0)$

らず，場合によってはデータを補間する必要も生じ，このようにコ ントローラにおいて多くの時間を要する。

そこで本研究では, バンドパスフィルタ (BPF) のカットオフ周 波数を調節することで制御力の位相を調節し, 理想的な制御力と実 際に入力される制御力の位相差による制御効果一の影響を分析す る。なお, 理想的な制御力の位相とは, 既往の研究 7)で論じてい るように, 応答変位の位相に比べ制御力の位相が $1 / 4$ 周期進んでい る状態のことである。図 9 に示すように, 理想的な制御力と実際に 入力される制御力の位相差 $\varphi$ を，固有周期 $T$ を基準とした $0,(1 / 4)$ $T$ および $(1 / 2) T$ となる 3 種類とする。図 10 に一例として Ra0.2-1M1 モデルで用いた BPF の周波数特性を示す。図 10 では, 遅れ時間を 考慮し, 1 次モードの周波数成分における位相差 $\varphi$ が 0 となるよう にカットオフ周波数を調節している。なお, 図中の $\Phi_{1}$ は BPF によ り生じる 1 次固有周期における位相である。このように, 遅れ時間 を考慮し, BPF のカットオフ周波数を調節することで, 所定の位相 差 $\varphi$ を得ることが可能である。また, 高周波域のゲインが小さくな るため, 制御力の高周波成分が応答一与える影響を小さくした状態 での制御効果の分析が可能となる。なお, BPF により位相を進めて 調節することも考えられるが，位相を調節しない制御を理想とする と，実時間で位相が進むことはないため，また，位相を補償する制 御方法を適用した場合にも, アクチュエータやコントローラの不具 合等により遅れ時間が増加する可能性があるため, 位相を遅らせる 制御のみの分析を行う。

なお，本研究では，遅れ時間の影響により，固有周期の 1 周期分 または 2 周期分（Ra0.4 モデルの 3 次モードを制御する場合）遅れ た応答を制御することとなる。

\section{4. アーチ構造物のアクティブ制振実験における制御効果}

\section{1. 制御力と応答の位相差が制御効果に与える影響}

まず，制御力と屋根面応答の位相差が制御効果に与える影響を分 析する。入力波は加速度振幅 $30 \mathrm{~cm} / \mathrm{s}^{2}$ の sine1 波とし, 理想的な制 御力と実際に入力される制御力の位相差 $\varphi$ は $0,(1 / 4) T_{1},(1 / 2) T_{1}$ の 3 種類とする。なお, 対象とするモデルは Ra0.2-1M1, 目標とする 応答比に関する係数 $r$ は 0.8 とする。
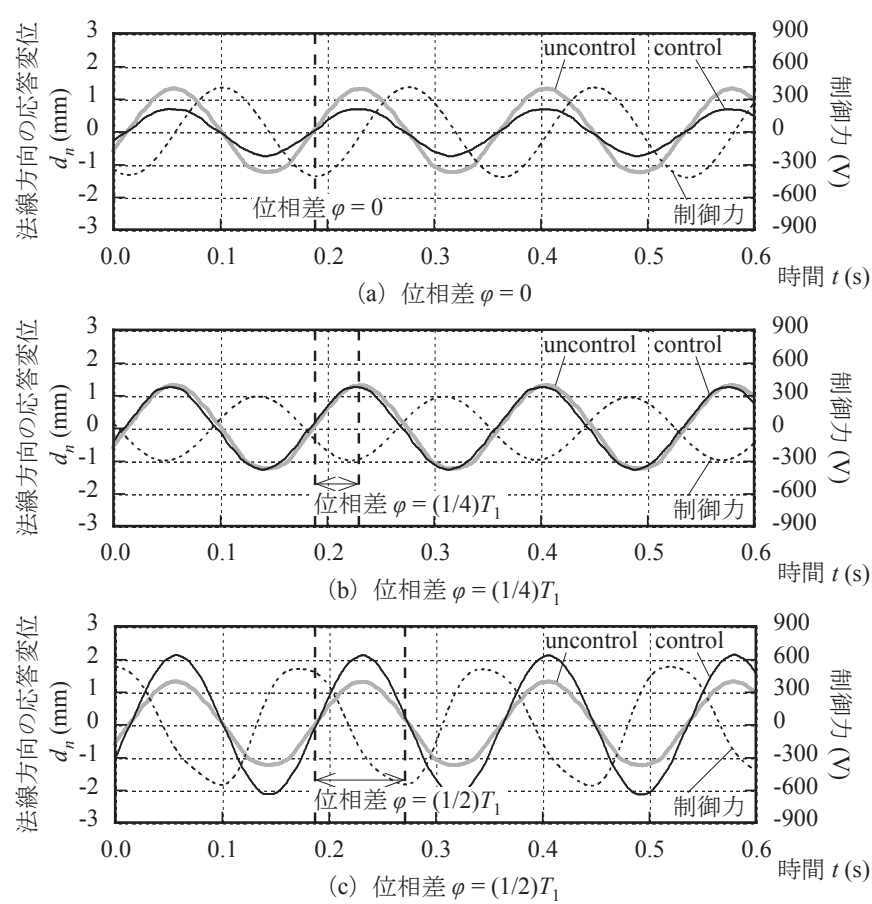

図 11 法線方向の応答変位および制御力の時刻歷 (Ra0.2-1M1, $r=0.8$, 点 3, sine1 波 $\left.\left(30 \mathrm{~cm} / \mathrm{s}^{2}\right)\right)$

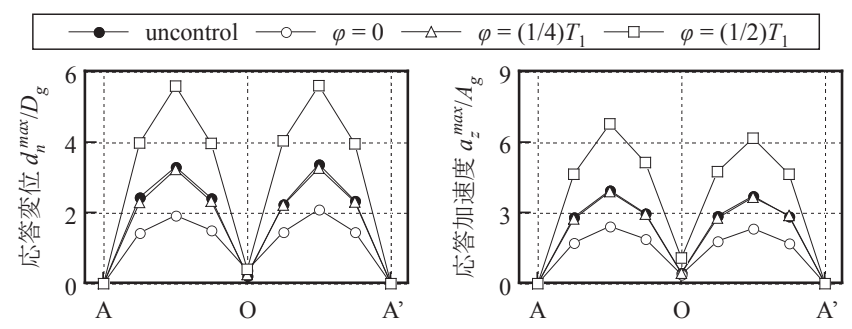

(a) 応答変位（法線方向）

(b) 応答加速度（鉛直方向）

図 12 最大応答分布 $\left(R a 0.2-1 \mathrm{M} 1, r=0.8, \quad \operatorname{sine} 1\right.$ 波 $\left.\left(30 \mathrm{~cm} / \mathrm{s}^{2}\right)\right)$

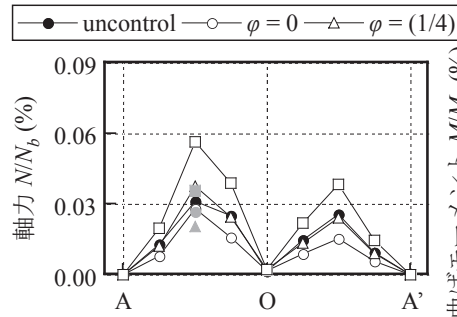

(a) 最大軸力分布

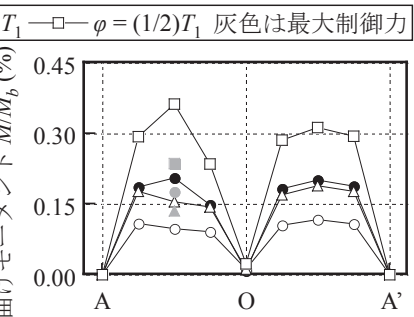

(b) 最大曲げモーメント分布
図 13 最大部材力分布 (Ra0.2-1M1，r=0.8, sine1 波 $\left.\left(30 \mathrm{~cm} / \mathrm{s}^{2}\right)\right)$

図 11 に各位相差 $\varphi$ における 1 次モードの腹にあたる点 3 の法線 方向の応答変位および制御力を時刻歴で示す。位相差 $\varphi$ が 0 の場 合, 応答変位は非制御時に比べ約 4 割低減した。位相差 $\varphi$ が (1/4) $T_{1}$ の場合, 応答変位に変化は見られない。位相差 $\varphi$ が $(1 / 2) T_{1}$ の場合, 応答変位は約 7 割増加した。このように, 理想的な制御力との位相 差が大きくなるほど, 制御による応答低減効果は小さくなる。なお, 位相差 $\varphi$ が $(1 / 4) T_{1}$ のときの制御力は, 他の位相差 $\varphi$ の場合に比心゙ 小さな值をとる。これは, 最適制御理論によるアクティブ制振では, 制御力の算出に対して, 応答変位よりも応答速度による依存度が高 いためであると考えられる。

図 12 に各位相差 $\varphi$ における法線方向の最大応答変位分布およ び鉛直方向の最大応答加速度分布を示す。ここに, 最大応答変位 
$d_{n}^{\max }$ は非制御時に計測された入力波の最大変位 $D_{g}$ で, 最大応答加 速度 $a_{z}^{\max }$ は計測された入力波の最大加速度 $A_{g}$ で除して示す。最大 応答变位分布および最大応答加速度分布は, 制御の有無および位相 差 $\varphi$ によらず，点 $\mathrm{O}$ に対し対称な二山となる。制御による応答の 増減は，変位および加速度で同程度であり，位相差が 0 の場合では 応答は低減し, 位相差が $(1 / 4) T_{1}$ の場合では応答に変化は見られず, 位相差が $(1 / 2) T_{1}$ の場合では応答は増加する。

図 13 に各位相差 $\varphi$ における最大部材力分布を示す。ここに, 最 大部材力は, 破断軸力 $N_{b}$ または, 縁応力が引張強さに達する時の 曲げモーメント $M_{b}$ で除して示す。最大制御力は, 印加した電圧か ら圧電フィルムのひずみ - 電圧特性を用いて求めたひずみにより算 出した。最大部材力に関しても, 制御入力位置を除いて, 位相差が 0 の場合では低減し, 位相差が $(1 / 4) T_{1}$ の場合では変化は見られず, 位相差が $(1 / 2) T_{1}$ の場合では増加する。なお, 応答が低減する $\varphi=0$ における最大制御力は, 非制御時の応力と同等程度である。位相差 が $(1 / 4) T_{1}$ の場合は, 計測された曲げモーメントの逆位相を制御力 としてフィードバックすることを意味している。しかし，このよう に計測された曲げモーメントの逆位相を制御力として入力するだけ では, 制御入力位置の曲げモーメントが低減する効果しか得られ ず，構造物全体の応答低減には至らない。

以上の結果から, 応答変位の位相に対して制御力の位相が $1 / 4$ 周 期進んでいる状態 $(\varphi=0)$ において, 応答の低減効果が得られるこ とが確認できる。この制御力の位相は, 最適制御理論を用いて得ら れる制御力の位相と等しい。つまり, 制御力は応答速度に比例して おり, 制御対象構造物に減衰を付加する制御方法であると言える。 以降では, 応答を低減させるために, 制御力の位相は理想的な制御 力と同位相 $(\varphi=0)$ の場合 (応答変位の位相から $(1 / 4) T_{1}$ または $(1 / 4)$ $T_{3}$ 進めた場合）について検討する。なお，制御効果の分析という 点における減衰定数の影響は小さいと考えられるものの, 本試験体 の減衰定数は実構造物よりも大きく, この影響は今後詳細に分析し ていく必要がある。

\section{2. 制御入力位置および制御入力数が制御効果に与える影響}

本節では, 制御入力位置および制御入力数が屋根面応答に与える 影響について, sine 波を入力することで分析する。なお，目標とす る応答比に関する係数 $r$ は 0.9 とする。

各制御モデルにおける sine 1 波に対する法線方向の最大応答変位 分布を図 14 に示す。最大応答变位分布は, 点 $\mathrm{O}$ に対し対称な二山 となり, 応答は一様に低減する。1 $1 \mathrm{M} 1$ モデル, $2 \mathrm{M} 1 \mathrm{a}$ モデル, $2 \mathrm{M} 1 \mathrm{~s}$ モデルの順に応答の低減が大きい。

図 15 に各制御モデルにおける sine 1 波に対する最大曲げモーメ ント分布を示す。非制御時に比べ最大曲げモーメント分布は低減す る。また, $2 \mathrm{M} 1 \mathrm{~s}$ モデルでは, 最大制御力は他のモデルと概ね同等 であるものの, 応答の低減量は大きい。一方, $2 \mathrm{M} 1 \mathrm{a}$ モデルでは, 1 次モードの腹でない点 4 に設置した圧電フィルムの制御力が小さ く, 結果的に応答の低減も $1 \mathrm{M} 1$ モデルとほぼ変わらない。つまり, 同程度の応答低減を実現する場合には，モードの腹における制御入 力数を増やすことで, 1 入力あたりの最大制御力を小さく抑えるこ とが可能となる。制御入力数が多く, 制御入力位置がモードの腹に 近いほど, 制御効果が高いといえる。

次に, 遅孔時間に対する相対的な周期が, sine 1 波に比べて短い 3

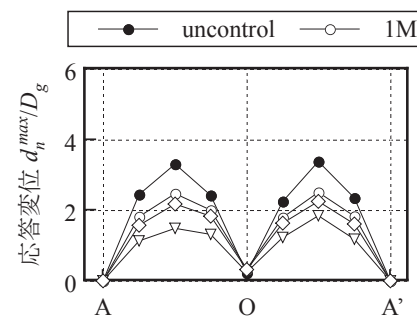

(a) Ra0.2 モデル

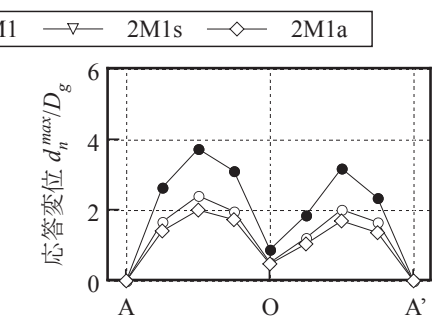

(b) $\mathrm{Ra} 0.4$ モデル
図 14 最大応答変位分布 (法線方向, $r=0.9, \quad$ sine1 波)

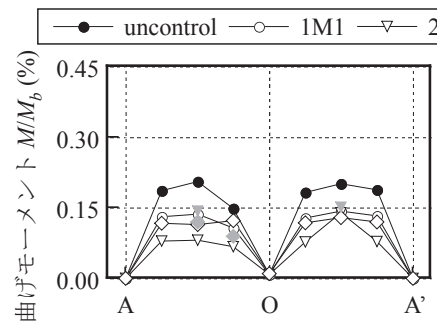

(a) $\mathrm{Ra} 0.2$ モデル

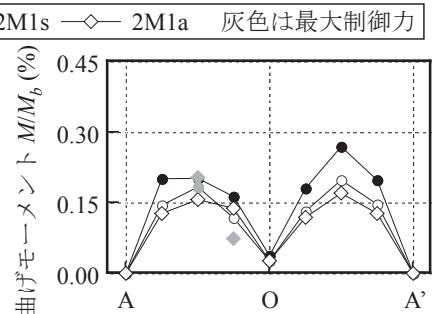

(b) $\mathrm{Ra} 0.4$ モデル
図 15 最大曲げモーメント分布 $(r=0.9$, sine1 波 $)$

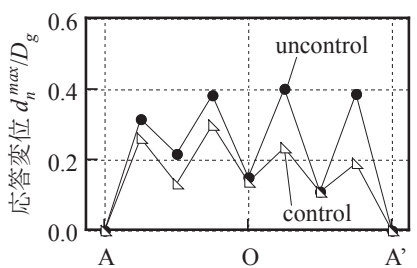

(a) 応答変位（法線方向）

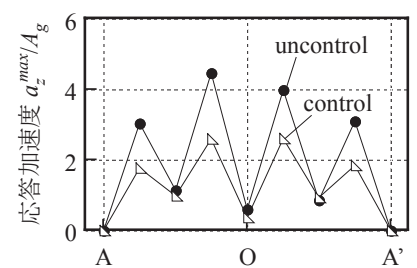

(b) 応答加速度（鉛直方向）
図 16 最大応答分布 $\left(\mathrm{Ra} 0.2-1 \mathrm{M} 3, r=0.9, \operatorname{sine} 3\right.$ 波 $\left.\left(40 \mathrm{~cm} / \mathrm{s}^{2}\right)\right)$

次固有周期と同周期の正弦波（sine 3 波）に対する制御効果を分析 する。ここでは， 3 次モードの腹に制御力を加える $1 \mathrm{M} 3$ モデルに おける制御結果の分析を行う。図 16 に sine3 波に対する法線方向の 最大応答变位分布および鉛直方向の最大応答加速度分布を示す。最 大応答変位および最大応答加速度ともに, 分布形状は, 点 $\mathrm{O}$ に対 して対称な四山となり, 図 3 に示寸モード形状に対応している。ま た, 応答変位および応答加速度ともに, 1 次モードと同様, 3 次モー ドに対しても制御により応答が低減する。

\section{3. 地震波に対する制御効果の分析}

本節では, 地震波入力時の応答低減効果について分析する。既往 の研究 ${ }^{16)}$ では, 1 周期分遅れた制御力による地震応答制御において, 応答低減効果は認められないものの, 安定な応答が得られている。 本実験においても，アーチ構造物の応答の安定性および制御効果に ついて確認する必要がある。ここで, 地震波入力時の制御力と応答 の位相差は, sine 波に対する応答を低減させるために設定した場合 と同様 $(\varphi=0)$ とする。つまり, 制御力の位相を応答変位の位相 から, $1 \mathrm{M} 3$ モデルでは 3 次固有周期 $T_{3}$ に対して $(1 / 4) T_{3}$ 進めた場合 とし，その他のモデルでは 1 次固有周期 $T_{1}$ に対して (1/4) $T_{1}$ 進めた 場合とする。なお, 入力地震波は, 人工地震波 BCJ-L1, 観測地震 波 El Centro NS (1940) および JMA Kobe NS (1995) である。

まず, 地震波入力時における法線方向の最大応答変位分布を図 17 に示す。BCJ-L1 および El Centro NS 入力時は, sine 波入力時の ような明確な応答低減が見られない。一方, JMA Kobe NS 入力時は 応答の低減が見られ, sine 波入力時と同様に, $2 \mathrm{M} 1 \mathrm{~s}$ モデルの応答 が最も低減する。このように sine 波に比べ地震波に対する応答低減 


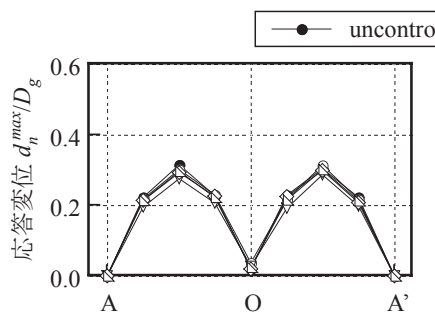

(a) BCJ-L1

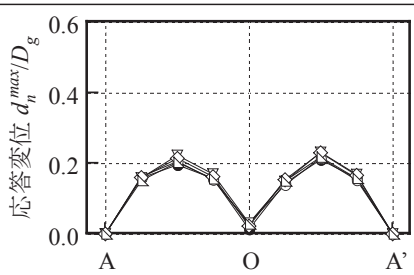

(b) El Centro NS

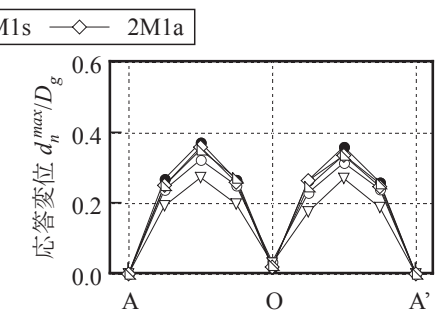

(c) JMA Kobe NS

図 17 最大応答変位分布 (法線方向, Ra0.2, $r=0.9$, 地震波 $\left(100 \mathrm{~cm} / \mathrm{s}^{2}\right)$ )

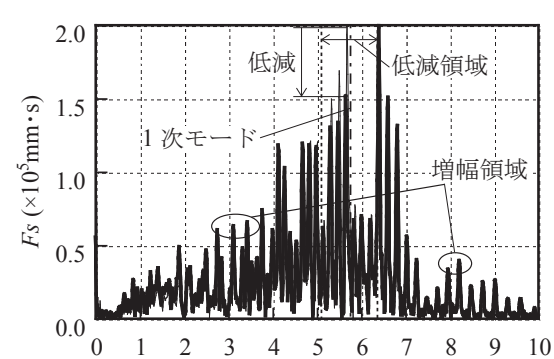

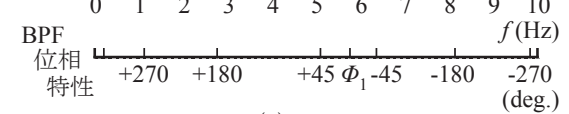

(a) BCJ-L1

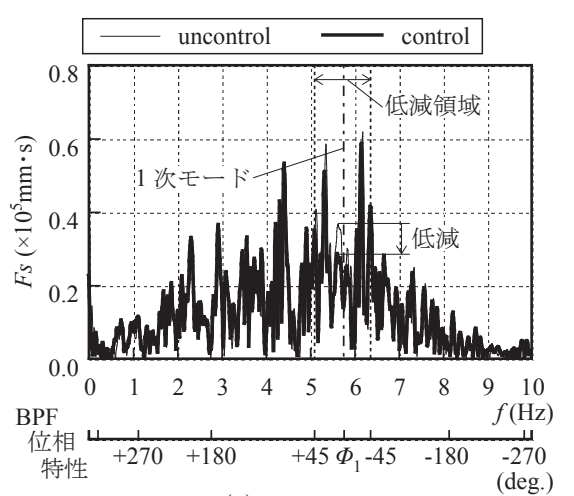

(b) El Centro NS

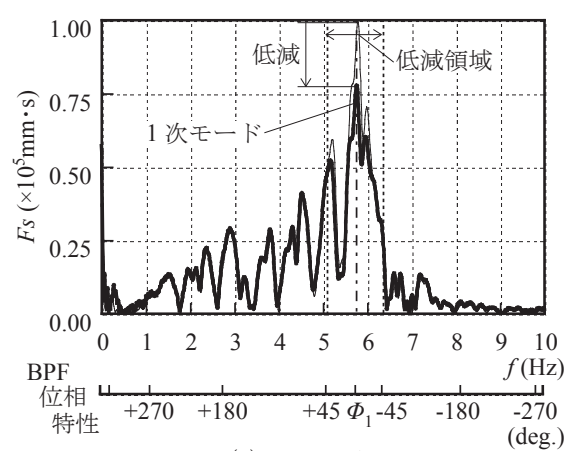

(c) JMA Kobe NS

図 18 法線方向の応答変位のフーリエ振幅スペクトル $\left(\operatorname{Ra} 0.2-1 \mathrm{M} 1, \quad r=0.9\right.$, 点 3 , 地震波 $\left.\left(100 \mathrm{~cm} / \mathrm{s}^{2}\right)\right)$

効果が小さい原因は, 制御力を応答から 1 周期分遅らせていること にある。位相を調節した結果，同じ形状の入力波形が連続する sine 波入力においては屋根面応答を低減できたものの，地震波のような ランダム波においては小さな応答低減効果しか得られなかった。

図 18 に, Ra0.2-1M1 モデルの点 3 における法線方向の応答変位 のフーリエ振幅スペクトルを示す。図の下部に, 各振動数に対する バンドパスフィルタ（BPF）の位相特性（図 10(b)）を併せて示す。 応答低減の見られなかった BCJ-L1 および El Centro NS 入力時にお いても, JMA Kobe NS 入力時と同様に, 1 次モード近傍の周波数 帯 $(5.75 \mathrm{~Hz}$ 近傍) では低減している。なお, この低減領域は概ね, BPF の位相特性が $\Phi_{1} \pm 45 \mathrm{deg}$. の範囲内にあたる周波数領域である。 また, $\Phi_{1} \pm 180 \mathrm{deg}$. の周辺に応答が増幅する周波数領域がある。た だし, この周波数領域におけるフーリエ振幅スペクトルは小さいた めに，応答への影響は小さい。しかし，想定している実構造物のよ うに, 本試験体よりも減衰定数が小さく, 複数のモードが励起され る場合には，制御により大きな増幅を生じる可能性がある。そのた め, このような構造物の場合には, 遅れ時間の補償方法を改良する ことで，低減領域となる周波数帯を広げる必要がある。なお，JMA Kobe NS 入力時の応答低減が他の地震波入力時に比べ大きいのは, アクティブ制振が卓越モードの周波数成分を多く持った波に対して 高い効果を示すためである。

sine 波入力時および地震波入力時の, 点 3 における法線方向の応 答変位のフーリエ振幅スペクトルにおける 1 次固有周期での制御に よる低減率を図 19 に示す。なお，低減率とは，制御時と非制御時 の值の差を非制御時で除したものである。目標とする応答比に関す る係数 $r$ が小さいほど, フーリエ振幅スペクトルの低減率は大きく なる。ただし， 3 次モードの制御を目的とした $1 \mathrm{M} 3$ モデルでは，r が小さくなるに伴い，低減率は負となり 1 次固有周期に対するフー リエ振幅スペクトルは増加する。また, 入力波によらず, 制御入力

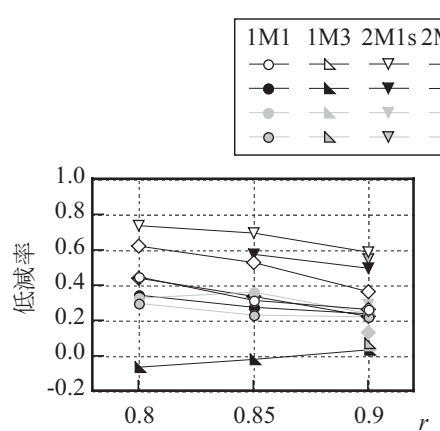

(a) $\mathrm{Ra} 0.2$ モデル
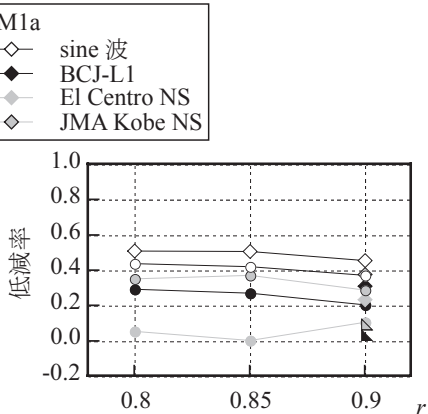

(b) $\mathrm{Ra} 0.4$ モデル
図 191 次固有周期におけるフーリエ振幅スペクトルの低減率 (法線方向の応答変位, 点 3 )

数が多く, 制御入力位置がモードの腹に近いほど, 低減率は大きい。 なお, Ra0.4 モデルの $r$ が 0.8 の場合には, 制御力が上限值 $( \pm 600 \mathrm{~V})$ に達するため，低減率が低い值となっている。

\section{5. 遅れ時間を考慮したアクティブ制振解析による応答評価}

\section{1 . 解析概要}

制御系の設計に用いた 9 質点アーチモデル（図 5) を対象として, 遅れ時間を考慮したアクティブ制振に関する時刻歴応答解析を行 う。解析方法は, 著者らによる文献 7) を基本とする。ここで, 解 析に用いる制御系は，アクティブ制振実験において実装した制御系 （図４におけるDSP に相当する部分）と同一とする。遅れ時間を， 実験で計測された值（表 7）とし，Ra0.2 モデルでは $18 \mathrm{ms，Ra0.4}$ モデルでは $78 \mathrm{~ms}$ とする。また, 制御力の位相 $\varphi$ は 0 (応答変位の 位相から (1/4) $T_{1}$ 進めた場合）とする。本研究では, 解析モデルは 弾性とし, 長期荷重は考慮しない。入力波は, アクティブ制振実 験で計測された振動台上の加速度とする。なお，MATLAB 7.10.0/ Simulink 7.5 を用い, 可変ステップソルバにより数值積分を行う。 数值積分法はルンゲクッタ法とする。 


\section{2. 時刻歴応答解析による実験結果の評価}

図 20 に実験と解析における $1 \mathrm{M} 1$ モデルの最大制御力の比較を示 す。最大制御力の実験值と遅れ時間を考慮した解析值は，概ね良い 対応を示す。遅れ時間の考慮の有無で解析值を比較すると, 遅れ時 間を考慮することで, 最大制御力は小さくなる傾向にあることがわ かる。これは, 遅れ時間を考慮していない場合, 応答と制御力の位 相の関係がずれ, 応答が低減しないために, 応答および制御力がと もに大きくなる傾向にあるためである。また, 特に sine1 波入力時 や Ra0.4 モデルの地震波入力時においては, 遅れ時間を考慮した場 合に解析値よりも実験值の方が大きな值をとる。これは, 解析にお いて, 重力や初期不整を考慮していないためであると考えられる。

実験と解析における $1 \mathrm{M} 1$ モデルの点 3 の法線方向の応答変位の 比 $d_{n}^{c} / d_{n}^{u c}$ の比較を図 21 に示す。応答変位の比 $d_{n}^{c} / d_{n}^{u c}$ は, 制御時の 最大応答変位 $d_{n}^{c}$ を非制御時の最大応答変位 $d_{n}^{u c}$ で除したものであ る。モデルによらず, 遅れ時間を考慮することで, 解析值は実験值 と良い対応を示す。 Ra0 .2 モデルに比べ $\mathrm{Ra} 0.4$ モデルでは, 固有周 期に対する遅れ時間の割合が大きいため, 遅れ時間の考慮の有無に よる解析值の差異が大きい。

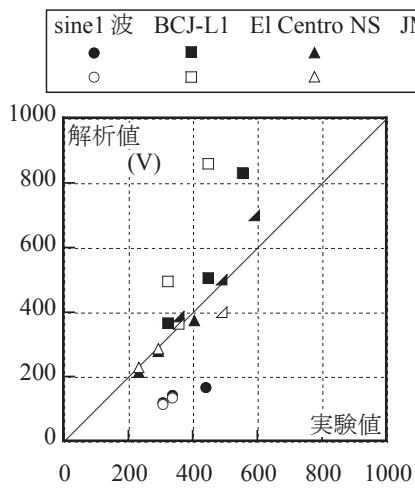

(a) $\mathrm{Ra} 0.2$ モデル

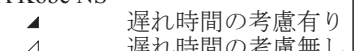
$\triangle \quad$ 遅れ時間の考慮無し

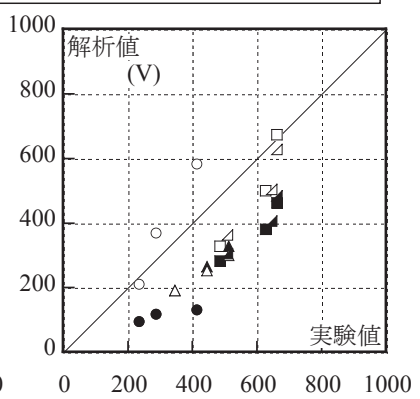

(b) $\mathrm{Ra} 0.4$ モデル
図 20 実験および解析における最大制御力の比較 (1M1)

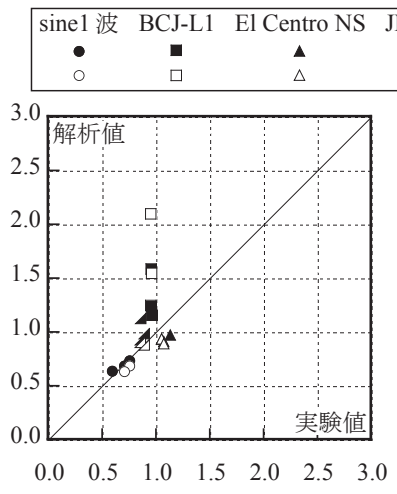

(a) $\mathrm{Ra} 0.2$ モデル

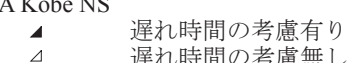
$\triangle \quad$ 遅れ時間の考慮無し

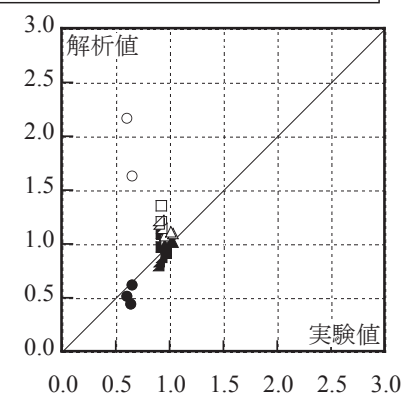

(b) $\mathrm{Ra} 0.4$ モデル
図 21 実験および解析における法線方向の応答変位の比 $d_{n}^{c} / d_{n}^{u c}$ の比較 (1M1)

\section{6. 結}

本研究では, アーチ構造物を対象にアクティブ制振実験を行うこ とで,アクティブ制振の基本的な特性の把握を試みた。本機構にて アクティブ制振を行うにあたり, コントローラにおける制御力の計 算時間などのタイムラグが制御の遅れ時間として発生した。そこ で, 制御効果一の遅れ時間の影響, 制御力の応答に対する位相差の
影響などを分析した。以下に本研究により得られた知見を示す。

1) 既往の研究 ${ }^{7)}$ と同様に, 正弦波入力によるアーチ構造物のアク ティブ制振実験においても，応答変位の位相に対して制御力の 位相が $1 / 4$ 周期進んでいる状態において，アクティブ制振によ る応答の低減効果が得られる。この位相から制御力がずれるほ ど，応答の低減は小さくなり増幅に至る。

2) 正弦波入力において同程度の応答低減を実現する場合には, モー ドの腹における制御入力数を増やすことで, 1 入力あたりの最 大制御力を小さく抑えることが可能となる。

3) 同じ形状の入力波形が連続する正弦波入力時は，応答を 6 割程 度に低減することができたものの，ランダム波である地震波の 低減効果は小さくなった。これは, バンドパスフィルタのカッ トオフ周波数により調節することで制御力の位相を 1 周期以上 遅らせたためである。

4）入力波によらず，制御力の応答変位に対する位相差を $1 / 4$ 周期 進んでいる状態とした制御対象モード近傍の周波数帯において は，アクティブ制振により応答を低減することが可能である。

5）制御時に発生する遅れ時間を考慮した時刻歷応答解析によるア クティブ制振の結果は，最大応答変位の低減率および最大制御 カともに，アクティブ制振実験の結果と良い対応を示す。

本研究では, シェル・空間構造物に適していると考えられる最適 制御理論による振動制御を行った。しかし，遅れ時間の補償のため にバンドパスフィルタを利用したことにより制御対象となる周波数 帯が限られ, さらに, アーチ構造物の振動モードの周期が近接して いないことにより，主要モードのみを抽出した制御となった。今後 の課題として, 遅れ時間の補償方法, 周期に対する遅れ時間の割合 の縮減等の改良を行い, 複数の制御入力による複数のモードを対象 とした制御の効果を検証することが挙げられる。また，本研究では 制御力の位相差 $\varphi$ を位相を遅らせる方向に設定したが，遅れ時間の ない理想的な最適制御力を目標とした，位相を進めた場合の制御効 果への影響については今後検討する予定である。

\section{謝辞}

本研究の一部は, 科学研究費補助金 基盤研究 (B)（課題番号 : 22360223）の助成を受けたものであり, 文部科学省 21 世紀 COE プ ログラム整備施設を用いて実施された。ここに謝意を表します。

\section{参考文献}

1) 日本建築学会 : 空間構造の動的挙動と耐震設計, 2006

2) 日本建築学会 : シェル・空間構造の減衰と応答制御, 2008

3) 楠達明, 薛 松涛, 山田大彦:TMDによる単層ラチスドームの振動制御, 構造工学論文集, Vol.41B, pp.17-22, 1995.3

4) 吉中 進, 川口健一: 分散型 MTMD による大スパン建築構造の振動制御 に関する研究 - 複数モード制御のための MTMD バンド幅設定法, 日本建築 学会構造系論文集, 第 608 号, pp.77-84, 2006.10

5) 吉中 進, 川口健一: 分散型 MTMD による大スパン建築構造の振動制御 に関する研究 - アーチモデルを用いた振動台実験, 日本建築学会構造系論 文集，第 621 号，pp.73-80，2007.11

6) 三松あずさ, 熊谷知彦, 小河利行, 富本 淳 : 複数の TMD を用いたアー チ構造物の振動制御，構造工学論文集，Vol.58B，pp.489-495，2012.3

7) 箕輪健一, 熊谷知彦, 小河利行 : 最適制御理論を用いたアーチ構造物のア 
クティブ制振，構造工学論文集，Vol.57B，pp.169-176，2011.3

8) S. Kato, S. Nakazawa, Y. Matue and T. Yamashita : Active Control of Axial Forces in Beam String Space Frames, IASS-ASCE International Symposium 1994, Atlanta, pp.664-673, 1994.4

9) 加藤史郎, 中澤祥二 : 張弦梁構造の軸力による多段階軸力制御 半質量夕 ンパーによる張弦梁構造の制振，構造工学論文集，Vol.41A，pp.123-132, 1995.3

10) 加藤史郎, 中澤祥二 : 静的荷重を受ける平面張弦構造の軸力決定法に関す る一考察，日本建築学会構造系論文集，第 474 号，pp.147-154，1995.8

11) 加藤史郎, 中澤祥二 : 幾何学的非線形性を考慮した張弦梁構造の初期導入 軸力決定法に関する一考察, 日本建築学会構造系論文集, 第 485 号, pp.8190, 1996.7

12) 中澤祥二, 加藤史郎 : ハイブリッド GA を用いた張弦梁構造のプレストレ 又導入部材最適配置の探索法に関する研究, 日本建築学会構造系論文集, 第 497 号，pp.99-105，1997.7

13) 桜井 宏, 半谷裕彦: 圧電シェルのセンシングと振動制御, 日本建築学会 構造系論文集，第 497 号, pp.107-114, 1997.7

14) 桜井 宏, 半谷裕彦: 圧電シェルのセンシングと振動制御 : 分割分布セン サとアクチュエーター, 日本建築学会構造系論文集, 第 504 号, pp.65-72, 1998.2

15) 坂井洋介, 桜井 宏: 圧電アクチュエータによる弾性はりの振動制御, 日 本建築学会東北支部研究報告集，第 62 号, pp.483-488, 1999.6

16) 久保哲夫, 佐藤博康, 本並洋二, 安田徳相 : FB 制御の AMD 制震システム
における制御時間遅れと安定に関する考察，日本建築学会東海支部研究報 告集, Vol.33, pp.141-144, 1995.2

17) 佐藤 健, 柴田明徳, 源栄正人，渋谷純一：建築構造物の複数固有モード 制約型地震応答制御解析 - 制御力の駆動時間遅れによる制御特性，日本建 築学会東北支部研究報告集, Vol.62, pp.475-478, 1999.6

18) 土谷武士，江上 正 : 現代制御工学 産業図書 1991，新版 2000

19) 美多 勉，向田昌幸：演算時間を考慮したディジタル制御系における並列 演算方式，計測自動制御学会論文集，Vol.18，pp.556-563，1982.6

20) 矢島尚人，黒川一夫：周波数特性に基づく実数次位相進み遅れ補償器を用 いた制御系設計法, 計測自動制御学会論文集, Vol.37, pp.56-64, 2001.1

21) 谷 順二, 三浦英久, 装 進浩, 大友規矩雄 : 圧電フィルムによるアーチ の振動制御，日本機械学會論文集 (C 編)，60 巻，570 号，pp.438-442， 1994.2

22) 江 鐘偉, 長南征二, 土屋敏弘 : PVDF 圧電フィルムセンサ・アクチュエー 夕の非線形動作特性, 日本 AEM 学会誌, Vol.2 No.1, pp.18-22, 1994.3

23) H.T. Banks, H.C. Lester and R.C. Smith : A Piezoelectric Actuator Model for Active Vibration and Noise Control in Thin Cylindrical Shells, Proceedings of the 31st Conference on Decision and Control, Tucson, pp.1797-1802, 1992.12

24) 尾崎晃一, 樽林達夫, 石坂昭夫 : ハーフパワー法による従来型推定式の減 衰比評価と実用的厳密解, マイクロメカトロニクス, Vol.48 No.2, pp.2031, 2004.6

25) 日本建築学会 : アクティブ・セミアクティブ振動制御技術の現状, 2006

26) 日本建築学会 : 建築構造物の振動制御入門, 2010 